\title{
A development agenda, the donor dollar, and voluntary failure
}

David Sutton, Rachel Baskerville,* and Carolyn Cordery

School of Accounting and Commercial Law, Victoria University of Wellington, Wellington, New Zealand.

*Corresponding author: Email: Rachel.Baskerville@vuw.ac.nz.

This paper examines the success and failure of a once pre-eminent New Zealand charity - the Council of Organisations for Relief Service Overseas (CORSO). Delivering aid for government was a factor in its success in its early years, as was its broad membership base. Voluntary failure occurred when CORSO lost government support. It also lost donor support when international charities established a competitive donor 'market'. Its supporters' unwillingness to 'buy-in' to its mission change to focus on local poverty was another factor in its collapse. This case study employs a framework which extends Salamon's (1987) to consider the influence of competition on voluntary failure.

Keywords: Voluntary failure; charitable organisations; CORSO; development history.

\section{Introduction}

Refugees displaced by wars and famines are an external manifestation of the cyclical failures which affect destabilised nation states and their citizens. Photos of displaced peoples exhibit a pathos opening donors' hearts and wallets to charities established to aid distress. Salamon (1987) recognises that voluntary organisations are the primary response mechanism to social need, but, like the people they aim to assist, charities may also experience cyclical growth and failure. Salamon (1987) formulated voluntary failure theory to explain why governments may respond to such failures at the meta-level. 
Robbins and Lapsley (2008) draw on Salamon (1987) and suggest that, in addition to government funding, strong stakeholder support is an explanatory feature in voluntary organisations' success. In this paper, we apply and extend Salomon's theory in the international development context to model the significance of competition for the donor dollar in circumstances of a voluntary organisation's failure. The organisation studied - the Council of Organisations for Relief Service Overseas (CORSO) - pursued an increasingly specific development agenda in the face of new competition from international charities. Thus it lost the support of a national community that had previously provided funding to aid the displaced and foreign poor. This longitudinal study of the demise of a giant in New Zealand charities, challenges the notion that voluntary failure is imposed from external parties alone, and highlights how jostling for the donor dollar may contribute to organisational failure.

CORSO, an umbrella organisation established to coordinate donations and overseas aid from a broad range of community and religious-based groups began in 1944. It grew rapidly to become New Zealand's premier aid agency, occupying this position for thirty years until it was overtaken in 1977 by a relative newcomer, World Vision. CORSO's narrowing focus from the late 1970s precipitated a serious decline; with donor fatigue and internal fragmentation reducing CORSO to relative obscurity by 1991 . The standard of financial records and financial performance reflect this change of direction. Until 1970 CORSO undertook careful budgeting and financial management, but this deteriorated from 1972 and financial systems functionally collapsed between 1986 and 1989 as the organisation became more internally focused.

Three aspects of Salamon's (1987) voluntary failure theory (as described in the following section) are evident in CORSO's history - philanthropic insufficiency, paternalism and, to some extent, particularism. CORSO risked philanthropic insufficiency in the 1960s, but it enlisted vital government support for its international development programmes to mitigate that threat. The rise of international charities in New Zealand in the 1970s exploited the philanthropic paternalism of the donating public at a time when CORSO's change of focus to incorporate development as well as local needs reflected a broadening of its agenda. The donors appeared to prefer charities delivering to those deserving of aid out of New Zealand, yet CORSO sought (what was then) radical change, unheeding the potential impact of philanthropic particularism. Finally, this discussion extends Salamon's (1987) voluntary sector service delivery failure to reflect causes of voluntary organisation failure. That is, 
Salamon's voluntary failure is of service delivery but it arises due to often astute pragmatic concessions to an immediate (donating) public demand. This supports voluntary organisational vitality at the cost of its mission.

This paper provides a valuable illustration of the importance of maintaining broad-based support in order to reduce the likelihood of donor disaffection and organisational failure.

Data for this research includes both secondary and archival sources. Secondary sources of both a general and CORSO-specific nature were located. Primary source documents in the form of annual reports, correspondence between member group representatives and the organisation, CORSO publications and press releases were accessed from the Alexander Turnbull Library; details of its organisational constitutions were obtained from the Registrar of Incorporated Societies. Primary sources used provided unique challenges, as data are often presented illogically, reflect bias or, in the case of annual reports, contain inconsistencies between years or are discontinuous. Secondary sources, in particular the CORSO 'biography' by Thompson (1969), the North and South magazine article (McLoughlin, 1991) and several newspaper articles, are replete with concise, although selective, information. Limitations of such secondary sources include the topicality of their focus. This dictates the chosen 'lens' through which CORSO was viewed and it creates temporal parameters around information utilisation.

\section{The theoretical frame}

A number of economic theories attempt to explain why voluntary organisations may be created, including the failure of the market or state to provide public goods and services (Hayes, 1996; Weisbrod, 1988) and an assumed trustworthiness factor that is not shared by counterparts motivated by profit (Ben-Ner and Gui 2003; Hansmann 1987; Seibel and Anheier 1990). Salamon (1987) argues that the rise of voluntary organisations is the direct result of market failure, with voluntary failure signalling the need for a government response. Voluntary failure has a variety of causes: Fernandez (2008) argues that young, small organisations will decline and that very few organisations fail due to declining socio-political legitimacy. Further, while Fernandez suggests that organisational decline is often related to mission completion and goal fulfilment, this case study does not support these findings. CORSO was large, and the 
pre-eminent New Zealand charity for over 25 years, yet it lost socio-political legitimacy: the rise of international charities precipitated CORSO's decline.

For this reason, the case study appears to align more with Salamon's (1987) voluntary failure theory which suggests four weaknesses in the voluntary sector in general as shown in Table 1. He uses organisational examples to describe the sector. In this paper, we extend Salamon's (1987) voluntary failure theory to organisations per se and the charitable 'market' in which a major organisation operated for over half a century.

\section{Table 1: Voluntary failure theory}

Philanthropic: Description

Unable to generate sufficient reliable resources adequate to Insufficiency meet human service needs. Salamon $(1987,39 / 40)$ notes this may be due to the economic environment or donor belief that they do not need to assist.

Focus on particular sub-group as 'deserving', leading to

Particularism duplicated services to this group. Resources will be wasted and the needs of 'undeserving' groups unmet. Salamon (1987, 40/41) calls this 'favoritism'. Funds channelled according to wealth-holders governing an Paternalism organisation who make allocations that inhibit social change. Salamon $(1987,41 / 42)$ describes this as the 'Lady Bountiful' heritage.

Vilification of professional services based on 'best practice' and expensive advertising. Amateur volunteers and low cost

Amateurism options are perceived to be 'charitable' and 'better'. Salamon $(1987,42)$ notes this is a largely early twentieth century phenomenon.

Source: Derived and extended from Salamon (1987)

As can be seen from Table 1, philanthropic insufficiency arises when beneficiaries' needs are greater than the funds and resources a charity is able to obtain. Faced by such insufficiency, an organisation may change its mission to generate more funds 
from a broader range (or a wealthier set) of public donors. Specifically, these fundsgeneration strategies may impose a change of mission or divert energies away from the beneficiaries that were initially targeted by the charity. Either way, insufficiency leads to voluntary failure.

Alternatively, while there may be enough funds to meet all of the community's needs, philanthropic particularism results in one segment being over-served and another under-served. At its extreme, particularism leads to resource wastage when services to particular sub-groups are duplicated and economies of scale are not developed. However, Brinkerhoff (2008) found particularism enabled Coptic Orphans to diversify its donor base beyond first generation Diaspora, so particularism may not, on its own, lead to failure, as it enables a charity to define its niche. That niche does, however, need to be adequately supported so that insufficiency does not arise.

Philanthropic paternalism is a third source of failure described by Salamon (1987), when wealthier individuals and groups make decisions about which beneficiaries are 'deserving' and how they should be funded. The prime weakness of paternalism is in the dependency relationship created between society's wealth holders and those who are relatively poor. Salamon (1987) quotes the example of arts and culture voluntary organisations aimed at supporting pastimes of the wealthy at the expense of services desired by the poor. It could be suggested that paternalism inhibits social change as it requires the voluntary organisation to conform to the expectation of its wealthy donors, including the expectation that the charity will support those the wealth-holders deem worthy.

Finally, Salamon's (1987) voluntary failure theory defines philanthropic amateurism as a reflection of paternalism and insufficiency. A focus on voluntary effort, 'making-do' and shunning professionalism results in ineffective approaches to beneficiaries' problems (Crampton et al. 2000). Thus Salamon (1987) provides an essentially neo-classical lens in which a natural state of market completion is achieved by a combination of private business and the voluntary sector. A residual role arises for government only where either of these default components of the market fails.

In applying Salamon's theory, this case study is presented in three sections: the first covering the 25 years from 1944 (CORSO's formation) through its rise to pre-eminence; the second describing the period from 1970 to 1979 when three critical events caused structural change as CORSO re-evaluated its service delivery and position as solely an overseas aid provider; the third encompassing the 12-year period 
from 1980, when CORSO narrowed its mission by focusing on the determinants of poverty and poverty at home as it 'marched to obscurity'.

\section{CORSO's growth (1944-1969)}

CORSO was established on August 16th 1944 as an overseas aid coordination body. The founders of this coalition were the National Council of Churches, The Society of Friends, and Red Cross (NZ), all of whom sought to respond to the plight of dislocated refugees, specifically four million displaced Europeans post-World War II (Thompson 1969). New Zealand's civilian population had a keen sense of privilege, as accounts of servicemen returning from World War II highlighted that New Zealand had been spared many of war's physical destruction and extreme privations. This notion dictated CORSO's original objective to relieve suffering and dislocation caused by war (Lineham and Davidson 1987). Yet, the infrequent and localised military conflict in the years succeeding World War II led CORSO to extend its aid and relief overseas more generally, although it continued to reactively meet immediate humanitarian demands (CORSO Annual Report 1955, 1965).

Early on the organisation's primary aid focus was to Greece, Yugoslavia and Poland, although from 1947 CORSO extended its activities to China, aiding people adversely affected by the war with Japan (Thompson 1969). It coordinated the overseas relief activities of its constituent members, acting as a conduit for resources, material (including shoes, clothes and medicines) and funds, to overseas organisations dedicated to foreign aid (Lovell-Smith 1986; Thompson 1969). Principal amongst these bodies were those of the United Nations (UN), the UN Relief and Rehabilitation Agency and later, the United Nations Children's Fund. CORSO enjoyed success in its early period, even distributing material aid for the government with whom it collaborated to meet New Zealand's UN relief commitments (Tennant, O'Brien and Sanders 2008). CORSO played an integral role in New Zealand's social framework, receiving strong support from a cross-section of society. In addition, from 1951 onwards, CORSO ran annual, charitable cash appeals to the general public.

During this post-war period, relations between CORSO and successive governments were consistently positive. For example, when the Government lifted its war-induced restrictions on public charitable appeals, this was especially to help CORSO resource its activities. From 1961, the Government allocated CORSO grants 
from the National Lottery (the Golden Kiwi). Consistently favourable relations were maintained with subsequent governments until 1975. Indeed, Prime Minister (1957-60) Walter Nash willed CORSO a legacy. In this respect, state support reinforced the charity, and provided it with a way to access funding from the public.

The first twenty-five years of CORSO evidenced broadly steady growth, attributable to an inclusive structure favourable to a wide cross-section of member groups. The structure of CORSO to 1965 was one in which a centralised Executive Committee (answerable to member groups) interacted directly with (paid) field staff. CORSO received increasing fund inflows over that period: rising from an income of $\$ 172,000$ in 1952 to $\$ 2.3$ million in goods and \$700,000 in cash in 1965 (Thompson 1969). Figure 1 provides ongoing income and expenditure data. Growth was supported by a benign, stable social environment and limited competition from other charitable organisations, as few international aid charities had arrived in New Zealand to this time.

Figure 1: CORSO Annual income, budget and donations 1967-1979

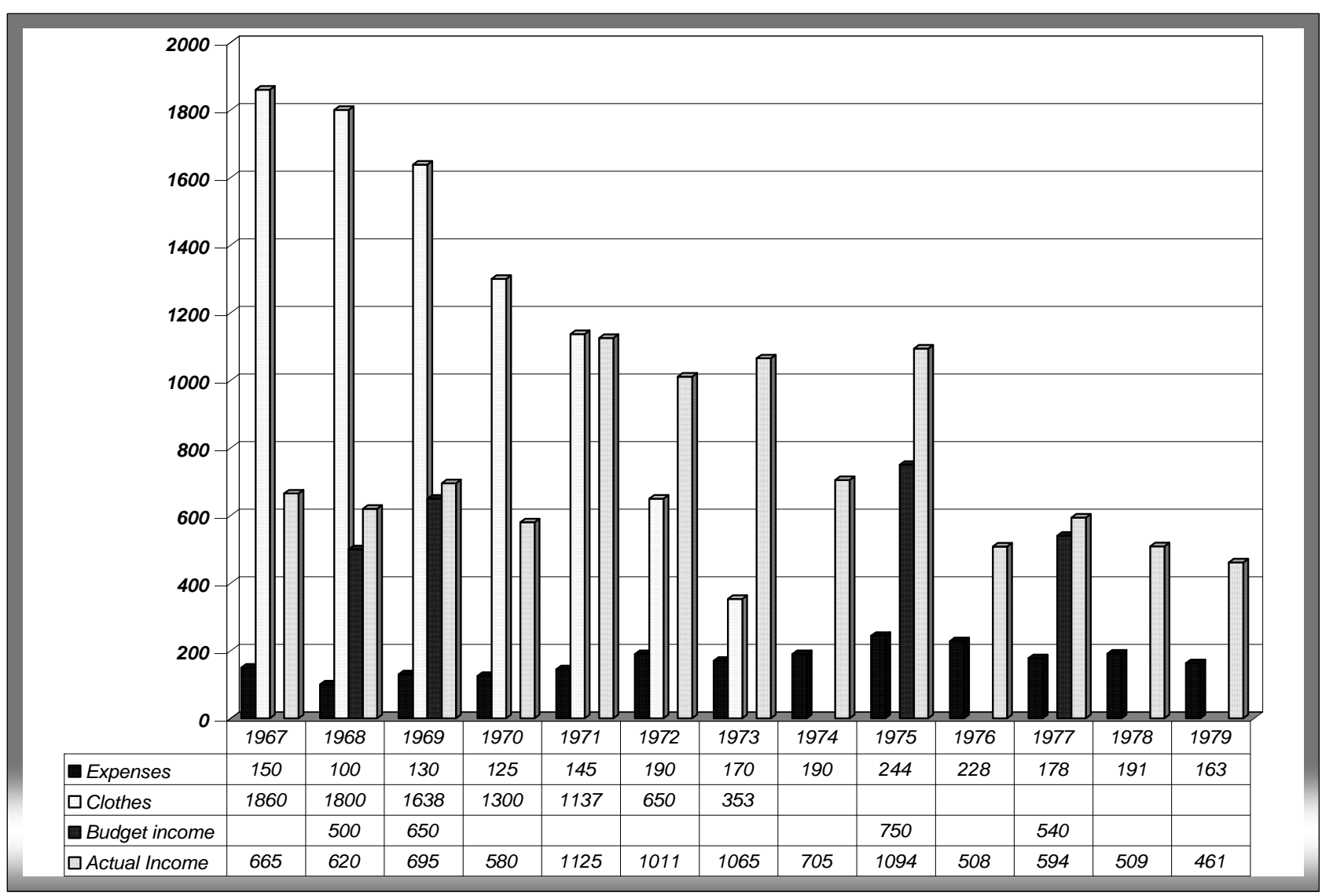

Source: CORSO Annual Reports: 1967-1982 
From 1965, CORSO's growth began to bring organisational challenges. Expansion and increasing organisational complexity necessitated decentralisation through the establishment of the following six sub-committees of the Executive: Finance and Property, Budget and Projects, Staffing and Administration, Publicity and Education, Material Aid, and Youth Against Hunger. Almost contemporaneously (from 1969) CORSO's field staff experienced a significant number of retirements. Thompson (1969) speculates that although the age and ill-health of certain staff was influential in the turnover at this time, the stress associated with the growing complexity of CORSO may have precipitated these retirements. These internal factors, combined with a steady growth in the number of charitable appeals, presented operating complexities and unexpected expenses. For example, in 1969 CORSO targeted 10\% in expenses (so that $90 \%$ of donations could go to their cause), but recognised that it needed to advertise in the face of growing competition and that this would lead to higher costs. Furthermore, political and social developments, from which CORSO was not immune, impacted all organisations. The increased participation of women in paid employment from the 1960s (Tennant 2001) reduced women's discretionary time for philanthropic activity and CORSO was particularly reliant on volunteers, due to the labour intensity of material aid handling and 'door-to-door' appeals. Workforce and lifestyle shifts were recognised as a challenge in Thompson's (1969) ‘biography' of CORSO, but he stated the organisation was confident in its ability to react to these changes. History shows his confidence was misplaced.

\section{0-1979: Impact of three critical events}

It was the changing social environment facing CORSO from 1970 onwards that precipitated its decline. As noted by Tennant, O'Brien, and Sanders (2008), global movements in environmental, feminist, indigenous and human rights were translated to the local context in the 1970s, and Māori became more visible in New Zealand society as a result of a growing cultural and political assertiveness. The combination of these factors began CORSO's 'long march to obscurity' (McLoughlin 1991) despite a brief renaissance in the mid-1980s.

While in the early 1970s, CORSO's constituent membership grew (see Appendix 1), internal friction arose between new member groups (who were not 
apolitical) and the traditional support base of CORSO (Roger 1974a, 1974b). The impact led to many members leaving between 1975 and 1980 (Appendix 1).

In this section, three episodes from the period 1970 to 1980 are described. Firstly, by 1972 a changing agenda emerged within CORSO bringing a focus on development rather than aid. Secondly, increased competition from international charities threatened CORSO's revenue stream. Finally, a focus on local poverty, coupled with a change in New Zealand's government, from Labour to National, caused a clash between the government and CORSO resulting in loss of significant government support, also important because government support had previously motivated CORSO's donors.

\section{Critical event one: aid vs. development}

By the 1970s, research had shown that reactive aid initiatives, the mainstay of CORSO's prior work, had achieved little long-term amelioration of poverty (Arnold and Glensor 1974; McNamara 1973). This realisation directed CORSO's attention progressively towards infrastructure development issues in overseas jurisdictions where they had previously provided aid. CORSO publications in 1972 and 1974 detailed the failure generally of aid agencies' initiatives from 1945 to 1972 in addressing the causes of poverty through a relief focus (Arnold and Glensor 1974). Over this period Balasuriya (1974) noted the relative economic position of developing countries had deteriorated in contrast to the post-World War II boom in North America and Australasia. From 1950 to 1970 the contribution to global exports of these developing countries declined from $32 \%$ to $18 \%$, on deteriorating terms of trade. In addition, their Gross National Product (GNP) grew by just 25\% from 1960-69, to a nominal average of US\$218 per capita, and developing country debt grew from US\$37.5 billion to US\$59.3 billion between 1965 and 1969. Small (1997) stated that Balasuriya's (1974) challenge was heard by every aid agency in the world, but few took action - perhaps due to a traditional, paternalistic attitude.

CORSO, however, responded to the deteriorating situation by focusing increasingly on the causes of underdevelopment and poverty (Balasuriya 1974). It saw the previous practice of providing material aid from 'clothes drives' as ineffective and (from the late 1960s) expensive when the cost of handling and transporting clothing was considered (CORSO Annual Report, 1968-1969). The 1968 Annual Report recorded an identified cost of $\$ 50,674$ but indicated that true costs, including 
depreciation, could have amounted to double that amount. ${ }^{1}$ Handling clothes consumed half of staff time. It was also noted that 'no one dies from a lack of clothes' (CORSO Annual Report 1968, 1969). Figure 1 shows the value of donated clothing plummeting over the period from 1967 to 1973. In 1974 clothing collections ended.

Despite its change of focus, CORSO continued to obtain government funds, but there were indications that a level of public wariness surrounded CORSO's transition towards development initiatives. The New Zealand public's general perception of overseas aid was that it should be geared to meeting people's immediate needs, relieving famine and hardship, rather than social change through development. This perception, whilst reflective of a lack of education concerning the value of development, caused public confusion over CORSO's programme (Otago Daily Times 2000). Two surveys conducted in 1973 are illuminating in this respect. From an admittedly small survey of twenty-six people, fifteen indicated they would not be prepared to donate to CORSO (Survey one 1973), with eighteen nominating CORSO as their least preferred charity. The report analyses reasons by gender. Men expressed concern in relation to the magnitude of administration costs and the amount of funds reaching the intended destination. Women believed that those active in the charity sought self-enrichment (some citing they had donated clothing for overseas aid only to see it being worn locally by CORSO collectors). Both groups expressed concerns that donated funds failed to reach intended beneficiaries and articulated a preference for charities focused on domestic needs (Survey one 1973).

These respondents voiced a primary concern that aid should respond to hunger, a point reiterated in a second more substantive survey (502 respondents) in which $66 \%$ identified hunger as the priority for aid (Research International Limited 1973). Although the survey indicated that a majority (71\%) approved foreign aid, most had limited understanding of the issues (Otago Daily Times 2000; Applied Research Consultants 1987). Here we see the New Zealand public's paternalistic attitudes towards supporting competition in the voluntary sector. International aid agencies crowded into the NZ aid market, precipitating CORSO's relatively reduced command of resources. A number of relatively high profile private sector appeals appeared to generate an increasingly widespread belief that charitable organisations were responsible for most overseas aid. In reality, the majority of overseas aid originated from the government (Applied Research Consultants 1987). In the later survey, only $15 \%$ of respondents stated CORSO should control aid distribution whereas $39 \%$ 
favoured the Red Cross and 21\% preferred government control (Research International Limited 1973). An inability to 'sell' its changed focus to development aid was steadily undermining CORSO's previous dominance.

Despite the education of CORSO's members on the development vs. aid issue, tensions emerged within the organisation between an increasingly diverse constituency of members. The more traditional membership base remained largely apolitical, seeking to extend aid and poverty relief to overseas destinations. In contrast, newer members sought far-reaching political changes, both internationally and domestically. Battles between these diverse groups for control of CORSO destabilised the organisation in the early 1970s. One such example was the contentious establishment of a division of CORSO called 'Action for World Development'. Key leadership personnel wished this body to be separate from CORSO. Their motion failed and they resigned (Roger 1974a, 1974b). Disquiet over CORSO's changing direction was also articulated at the fourth Annual Regional Conference held in Gore on 27th April 1974. Attendees were uneasy regarding the disparate nature of CORSO's 60 constituent members (CORSO Gore 1974) and stated that the organisation should confine itself to safe issues and avoid public criticism.

Structurally CORSO was, and remained, democratic. Voting powers were dispersed evenly amongst constituent members. Further, a decision was made at the 1975 AGM to extend CORSO's membership structure, admitting a new class of membership for individuals, and new consultation procedures, as shown in Figure 2. This change cemented the aim of increasing regional cooperation and communication by creating six regional committees with representation on the National Executive Council. The arrangements also required the election of two regional representatives to the Executive Committee that had direct oversight of operations. Yet the admission of individual and associate members into CORSO, at a time of growing internal political activism by some members, undoubtedly destabilised the organisation. 
Figure 2: CORSO's structure, subsequent to adoption of constitution at AGM 1975

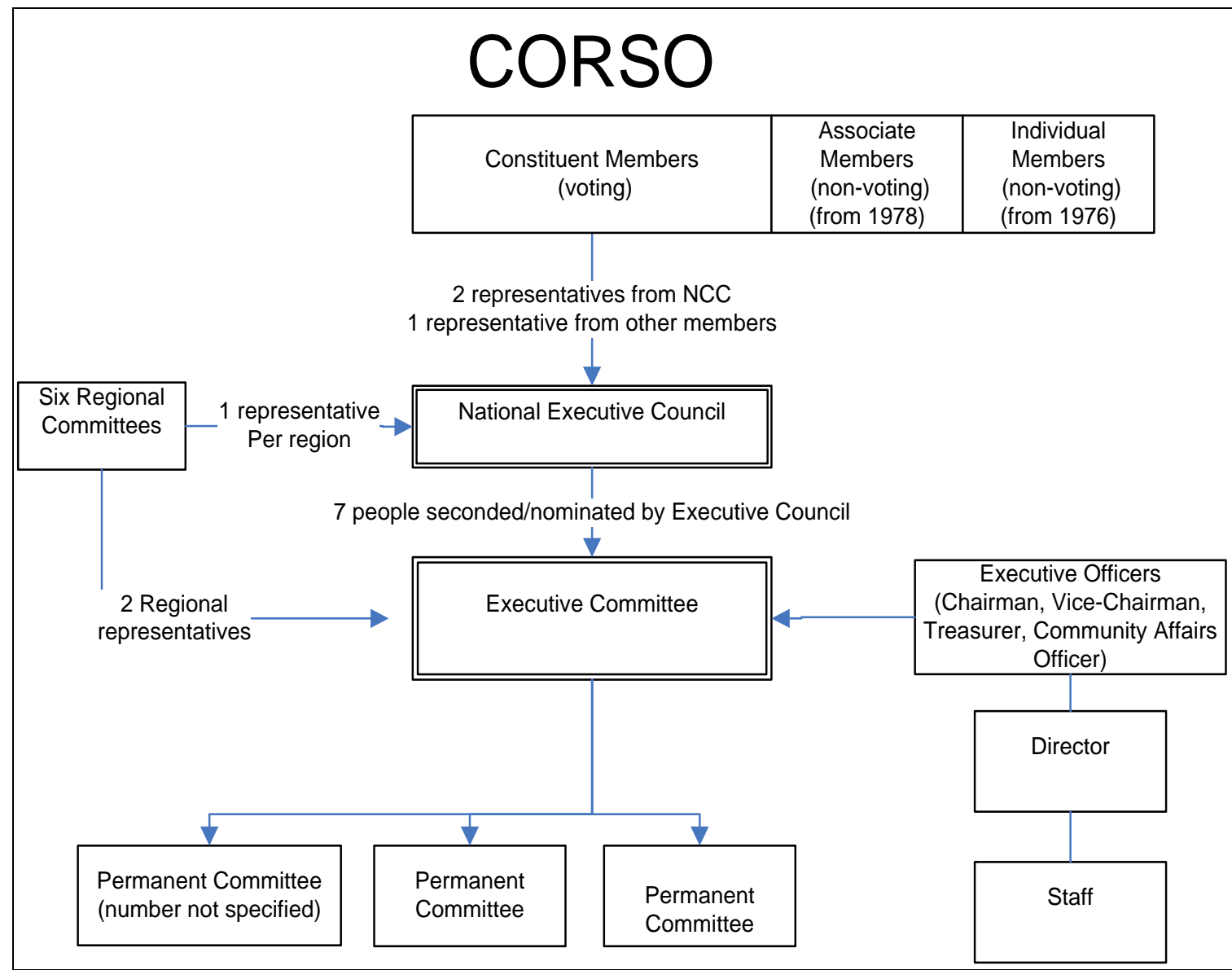

The early history of CORSO supported the value of inclusivity, concomitant with a substantially singular view of CORSO's mission. CORSO's leadership believed that they could reduce the growing dissent by establishing three clear aims for the organisation: relief, development, and educating New Zealanders on the causes of underdevelopment (CORSO Annual Report 1975).

Where the concept of 'capture' by some membership groups overstates developments, Appendix 1 clearly indicates much of CORSO's traditional support base no longer felt aligned to this evolving mission, reflected in constituent members' withdrawals from CORSO in the second half of the 1970s.

The annual financial accounts reveal difficulties in financing operations from 1970 (CORSO 1976). Previously, conservative budgets for the forthcoming year were published along with annual reports. The conservatism of these is reflected in 1967 
and 1968 publications where modest expectations were set in recognition of the recession New Zealand then faced from the collapse of the wool market (CORSO Annual Report 1967, 1968). Expenditure was budgeted to correspond with prudent income forecasts and adherence to budgeted expenditure was rigorous.

The 1970s experience, in contrast, was one of income falling below budget and declining (McLoughlin 1991). The 1974 Annual Report revealed the Treasurer expressing concerns over the level of income (down on budget) and the growing reliance on special appeals (non-recurrent income). Meanwhile, expenses were ahead of forecast (CORSO Annual Report 1974). As shown in Figure 3, a clear decline in resource inflows appears post-1973, showing the constitutional changes and re-stated aims had done little to stem the decline. Documentary evidence of public perceptions (noted above) confirmed a rising mistrust and, combined with societal changes already referred to, reduced donations to CORSO.

Figure 3: CORSO Income and Expenditure 1967-1991

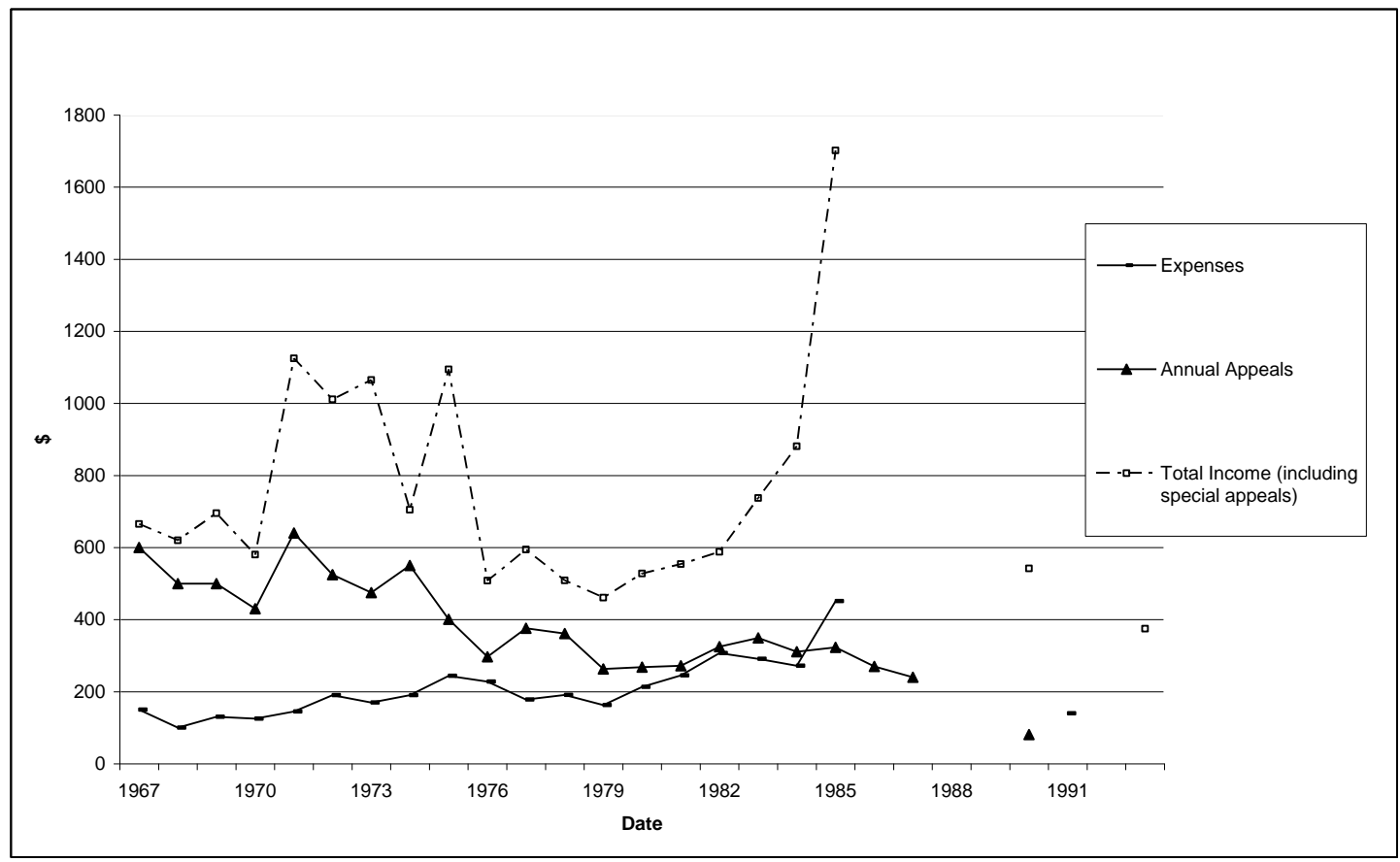

Source: CORSO Annual Reports: 1967-1982; 1985-1986; McLoughlin 1991;

Overview 1991, 1987; CORSO AGM 1990. 
The rising expenses revealed in Figure 3 are particularly important in light of public concerns that the proportion of appeal collections reaching those they were intended to benefit should be maximised (Survey one 1973; Research International Limited 1973). The 1978 Annual Report noted that expenses absorbed $36 \%$ of revenue. Financial indicators, while not being central to CORSO's decline, can be seen to reflect the impact of the organisation's changing 'fortunes', both financial and non-financial.

\section{Critical event two: Competition in the foreign aid market}

The 1970s evidenced the arrival of various international aid-agency charities to New Zealand. Previously, rivalry between charitable organisations had been restrained or low-key, especially as CORSO acted as an umbrella organisation for aid overseas. However, the establishment of the New Zealand office of World Vision in 1971 heralded increasing competition in the sector (McLoughlin 1991). World Vision remained untarnished by politicisation, and more closely corresponded with public perceptions of a politically-neutral international aid organisation at a time when television exposure of the demand for aid increased public awareness of global issues (Tenant et al. 2008). CORSO's profile was at variance with such international rivals.

These new organisations used television advertising coupled with street appeals, and engaged with donors by sending them personalised letters. For example, World Vision's 'Forty Hour Famine' mobilised youth, and child sponsorship schemes whereby the donor regularly received photos and letters from the sponsored child. These professional fund-raising tactics were at variance with CORSO's modus operandi and made CORSO vulnerable to the newly-arrived aid agencies' exploitation of the philanthropic paternalism of NZ society, result in declining donor dollars $^{2}$ (Small 1997). In addition, this new type of fund-raising required less labour than CORSO's door to door appeals and clothes collections and was more effective than CORSO's postal appeals.

The professional campaigns of these international charities proved successful in mobilising public support (McLoughlin 1991), and this is reflected in their income growth. In contrast, CORSO's public profile was one of an increasingly confused and factious political organisation. Figure 4 shows the extent to which other international aid agencies prospered compared to CORSO (Hutching 1994). World Vision's overseas experience in donor-mobilisation methods resulted in it becoming the largest 
aid agency in New Zealand by 1977 (Lovell-Smith 1986). Its income in 1990 was \$10.5 million and in 1992, \$17 million. In similar fashion, The Evangelical Alliance Relief (TEAR) Fund grew rapidly from its inception in New Zealand in 1974 (LovellSmith 1986), while Oxfam raised $\$ 611,402$ just two years after opening a branch in New Zealand (1990) (Consumer 1993). Small (1991) considered Oxfam's arrival as a 'foreign take-over bid' as it launched fundraising events that clashed with local charities (including the New Zealand Red Cross national appeal), promoted shops in competition to Trade Aid and justified its establishment by "putting about the lie that CORSO no longer existed'. A 1991 CORSO Newsletter rebuked the Christian Children's Fund for coming to New Zealand (Overview 1991). By 1992 that organisation raised funds of $\$ 2$ million.

A member of CORSO, but also an aid agency in its own right, the Christian World Service (CWS) experienced a similar range of external influences to CORSO (Lovell-Smith 1986). Despite this, CWS continued to grow and prosper (see Figure 4). CWS developed strong links with CORSO, with Pamela Gruber (the CWS leader from 1972-1976) serving on CORSO's Executive Committee and, as late as 1984, CORSO insisted that mutual trust existed between the two organisations. Yet the divergence in organisational fortunes, under similar conditions, suggests CWS was able to maintain its supportive church-based community of members which, as shown in the next section, CORSO eschewed. 
Figure 4: Incomes for Aid agencies in New Zealand 1972 and 1984

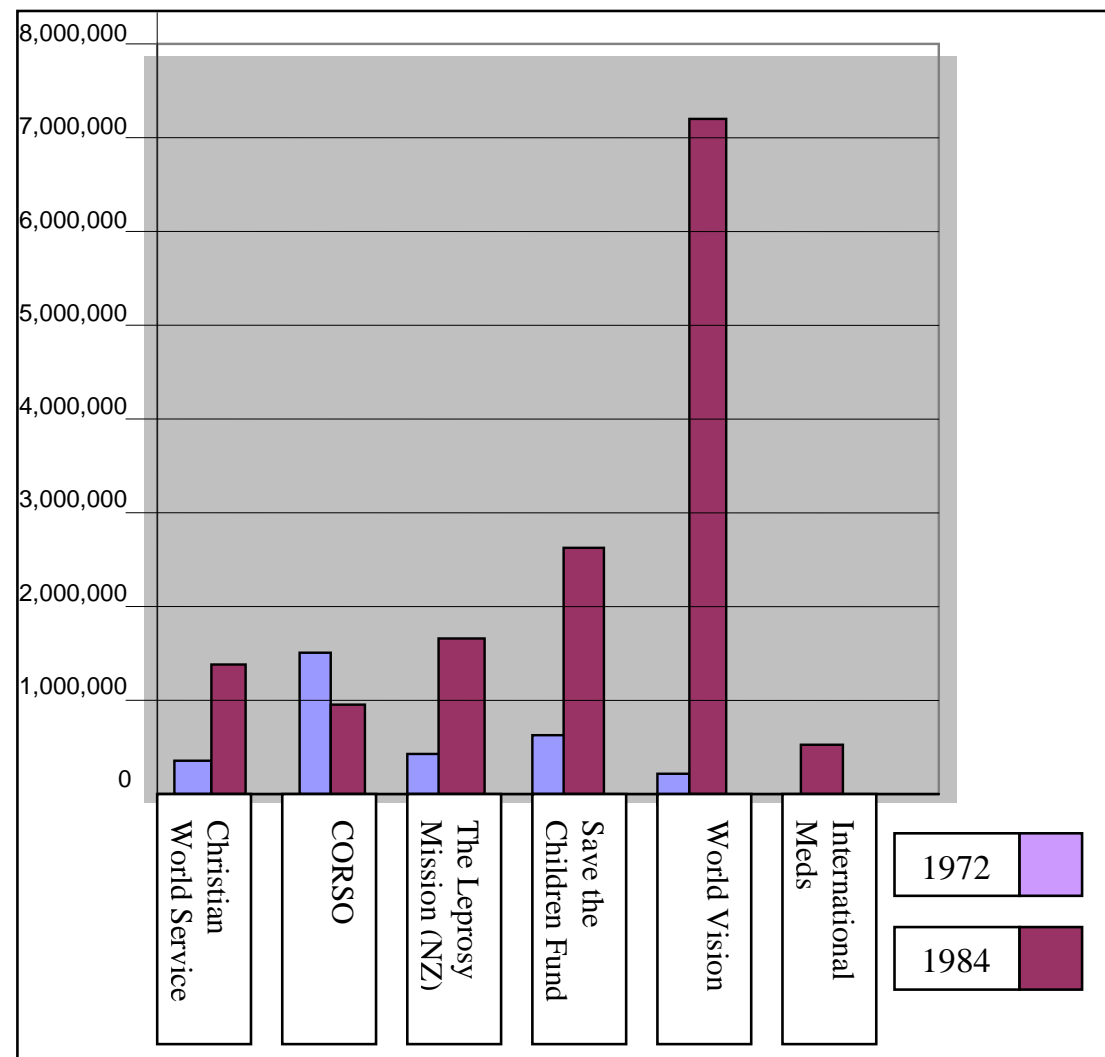

Note: In this graph only CWS and CORSO are New-Zealand centred.

\section{Critical event three: Loss of government support}

From 1972 CORSO's relief programme included a growing focus on poverty in New Zealand (McLoughlin 1991). Until 1975, relations with the Labour Government had been positive, but CORSO's new focus placed it in direct opposition when the National Party came to power in 1975 . As CORSO engaged in an increasing critique of New Zealand societal values, it also identified a lack of 'distributive economic justice,' highlighting injustices to Māori (McLoughlin 1991). Demands for acknowledgment of the Treaty of Waitangi and Māori self-determination (Tino rangatiratanga) escalated (Tennant et al. 2008). By 1975, the government had 
instituted the Waitangi Tribunal to address historic wrongs, but Chile (2006, p.422) noted 'many non-Māori people felt and continue to feel threatened by the Tribunal process'. CORSO was caught in this fight for social justice for Māori in New Zealand from a number of its new constituent members. Furthermore, CORSO changed its legal name in 1977 to the New Zealand Justice and Development Organisation but retained the trading name of CORSO for the purposes of stakeholder recognition.

CORSO's Director was replaced by a new office of General Secretary who was required to co-ordinate rather than direct, the organisation (CORSO Annual Report 1976). Successive annual reports $(1977 ; 1978 ; 1979)$ repeated calls for better communication between the national body of CORSO, its constituent members, and its regional bodies. The principal concern seems to have been to allay a sense of alienation felt by constituent members; the General Secretary commented in 1977 that CORSO had been stacked with 'church people' when he had assumed office, but much had been done to lessen its reliance on these groups through his tenure (CORSO Annual Report 1978; Lovell-Smith 1986). Such comments are further evidence of CORSO's admission of groups who were politically active. The newer groups included: the Campaign for Racial Equity (CARE) (1978), (the) Māori Council (1979), NZ Anti-Apartheid Council [later Halt All Racial Tours (HART)] (1979), NZ Public Service Association (PSA) (1980), NZ Values Party (1979) and Trade Aid (1975). Scope prohibits a detailed description of these groups, but they were more politicised than previous mainstream CORSO constituent members. HART coordinated protests against tours by apartheid-based rugby teams, events that divided New Zealand and CORSO (Annual Report 1982). The PSA associate membership was part of CORSO's new support base in organised labour (Annual Report 1980; Wellington Region Annual Report 1981), reflecting recognition by CORSO that they needed political allies in their mission change.

The government was displeased when CORSO granted $\$ 5,000$ to dissident groups subject to repression in Malaysia for publication of their newspaper, Mimbar (De Bres, Campbell and Harris 1974). Yet collision with government occurred when CORSO produced a film in 1979, titled A Fair Deal (CORSO Annual Report 1979). Television New Zealand (the national broadcaster) refused to screen this film which focused on labour exploitation in Hong Kong and aimed to educate the public of New Zealand's role in causing such poverty. The film, in combination with CORSO's attention to poverty amongst Māori and other disadvantaged groups in New Zealand 
society, caused a government backlash. Prime Minister Robert Muldoon was outraged at CORSO's representation that poverty existed in New Zealand and that New Zealand, through trade, was responsible for contributing to poverty overseas. He lamented the demise of CORSO's focus on aid and the emergence of its political agenda. Consistent with his forthright political style his reaction was swift. On 19 September 1979 the government removed CORSO's tax exempt status and ended a $\$ 40,000$ annual grant to the organisation (Hutching 1994).

Constituent members of CORSO remained broadly supportive of the organisation, the majority opposing the punitive government action. Letters and donations in support for CORSO came from diverse quarters, including Trade Aid (1979), The Values Party (1979), Volunteer Service Abroad (1979), the Pencarrow Labour Electorate Committee (1979), and others.

In contrast (although not agreeing with the government action) six constituent members or affiliate members expressed concern about CORSO's direction. The YMCA, in a letter dated 21 September 1979, requested the CORSO General Secretary to remain low key and focus on overseas aid (Government Action vs. CORSO 19789). The New Zealand Federation of University Women noted reservations about the quality of the educational materials CORSO was distributing (Government Action vs. CORSO 1978-9). Similarly, the National Council of Women of New Zealand (1979) expressed concern that $\$ 100$ had been spent on producing a Trades Council leaflet and indicated they would review their membership of CORSO in 1980. A letter from the Methodist Internal Affairs Committee (1979) suggested CORSO should re-assess its spending priorities.

Although financial results (particularly Appeal income) suggest a sympathetic reaction to the government 'collision' outweighed negative reaction, in terms of the public generally, indications exist of a level of mistrust engendered by this adverse publicity (Otago Daily Times 2000). Over the longer term, it appears the public were not prepared to support the radical political agenda presented by a uniquely New Zealand aid agency (Hutching 1994). Evidencing continued redirection of Government support, CORSO lost a grant it had received historically from the Ministry of External Affairs when the Ministry directed its resources through other organisations.

The progressive politicisation of CORSO was reflected in its call for a 'new economic order' (CORSO Annual Report 1978), and further entrenched when 
CORSO centralised the control of projects through a National Projects Officer in 1979 (CORSO Annual Report 1979).

\section{0-1991: CORSO's long march to obscurity}

In 1984 the General Secretary, Ross Stevens, implemented a 'Justice begins at Home' programme and developed the Māori Development Fund known as the Aotearoa Puutea Fund (from 1986) (CORSO Newsletter 1994). The strengthening New Zealand focus of CORSO was encapsulated in this fund's aims to utilise two-thirds of CORSO's income within New Zealand (CORSO Annual Report 1986), a further indication of the changing mission of CORSO. Arguably, from Salamon's (1987) theory of voluntary failure this reflected a positive development towards the optimal delivery of voluntary sector public goods, meeting an under-served part of the market. However, the failure of CORSO to persuade the donating public of this need, and the competition for the donor dollar, were important in CORSO's decline.

In 1986 the Aotearoa Puutea Fund gained a full-time coordinator, H. Halkyard Harawira (CORSO Annual Report 1986) and in the same year a CORSO newsletter presented the then radical view that the Treaty of Waitangi was a fraud (CORSO Newsletter 1986). ${ }^{3}$ The resulting dissent in debates between Māori and non-Māori members of CORSO overflowed at the AGM in 1988 into physical violence (Woodward 1990). This snapshot from the AGM foreshadows the later demise of CORSO as a national charity.

In 1979, as previously noted, donations had decreased, but an increase occurred in 1980 , from $\$ 461,000$ to $\$ 528,000$ (CORSO Annual Report 1980). ${ }^{4}$ This trend continued through 1984, amplified by the flow-on effect of international multimedia fund-raising events such as the 1985 'Live Aid' event (CORSO Annual Report 1985). As any other plausible explanation is absent, the sympathetic reaction by stakeholders to 'bullying' by the Prime Minister (in 1979) appears the likely driver (CORSO Annual Report 1980). This peak of income in 1985 was on the back of a general increase in public awareness of international aid projects. But, thereafter, CORSO's fortunes progressively declined relative to the growth in other agencies.

Figure 3 shows CORSO's income and expenses over this period. The 1985 spike in income is indicative of the increase in the profile of the need for international aid; it does not reflect any fundamental revitalisation of CORSO. This is supported by 
its subsequent decline of revenue in the latter half of the 1980s. What is illustrative of organisational ill-health from Figure 3 is the convergence of CORSO's expenses and annual appeal income, CORSO's principal recurrent source of unencumbered funds. Inflation adjustment essentially flattens the slight increase in expenses; thus when income is adjusted for inflation, a decline in real terms from 1971 is evident (McLoughlin 1991).

Expenditure on community awareness and education more than doubled from 1983 to 1985 , to $\$ 156,466$ (CORSO Annual Report 1983, 1985), but this did not improve its donations. The falling income from annual appeals reflected dissatisfaction from its previously strong donor support base who may have perceived CORSO as a radical, politicised organisation (CORSO Newsletter 1978; CORSO Annual Report 1983).

Although not unique to CORSO, growing donation specification from 1985 contributed to inflexibility of funds application (Hutching 1994). CORSO's 1986 Annual Report refers to financial difficulties related to increasing specification of both donations and legacies. For example, in 1984 \$63,617 of donations were specified relative to $\$ 880,000$ total income (7.2\%), but this increased to $\$ 453,234$ in 1985 against of \$1.7 million total income (26.6\%) (CORSO Annual Report 1986). Growing donation specification from 1985 contributed to inflexibility of funds application (Hutching 1994). One measure to ameliorate disaffection was a constitutional structural change (as shown in Figure 5).

The constitutional change was undertaken to increase the regional representation in CORSO's National Coordinating Group. However, this failed to increase confidence in and revenue for, CORSO. By 1989, CORSO was in financial crisis. Organisational tensions reduced fund raising effectiveness, as revealed in letters (e.g. Duke 1990) and in the record of CORSO's 1990 AGM. At the Annual Assembly CORSO's Auckland branch proposed a motion to disband CORSO, due to these tensions and lack of funds (Duke 1990). Long-term budgeting problems, excessive costs, competition from the advent of a new national lottery and general economic stress in New Zealand from the economic restructuring of the 1980s had exacerbated CORSO's situation. No annual accounts were produced between 1986 and 1989 (CORSO AGM 1990). The 1990 annual report presents a balance sheet in which negative net assets are stated at $\$ 194,596$, corresponding approximately with the over-budgeting for that year's annual appeal $(\$ 109,000$ had been collected against 
an anticipated $\$ 300,000$ ). Mounting debt resulted in all but two staff being sacked, yet local expenses still consumed 51\% of CORSO's income (CORSO AGM 1990).

Figure 5: CORSO's structure, as revised in 1987

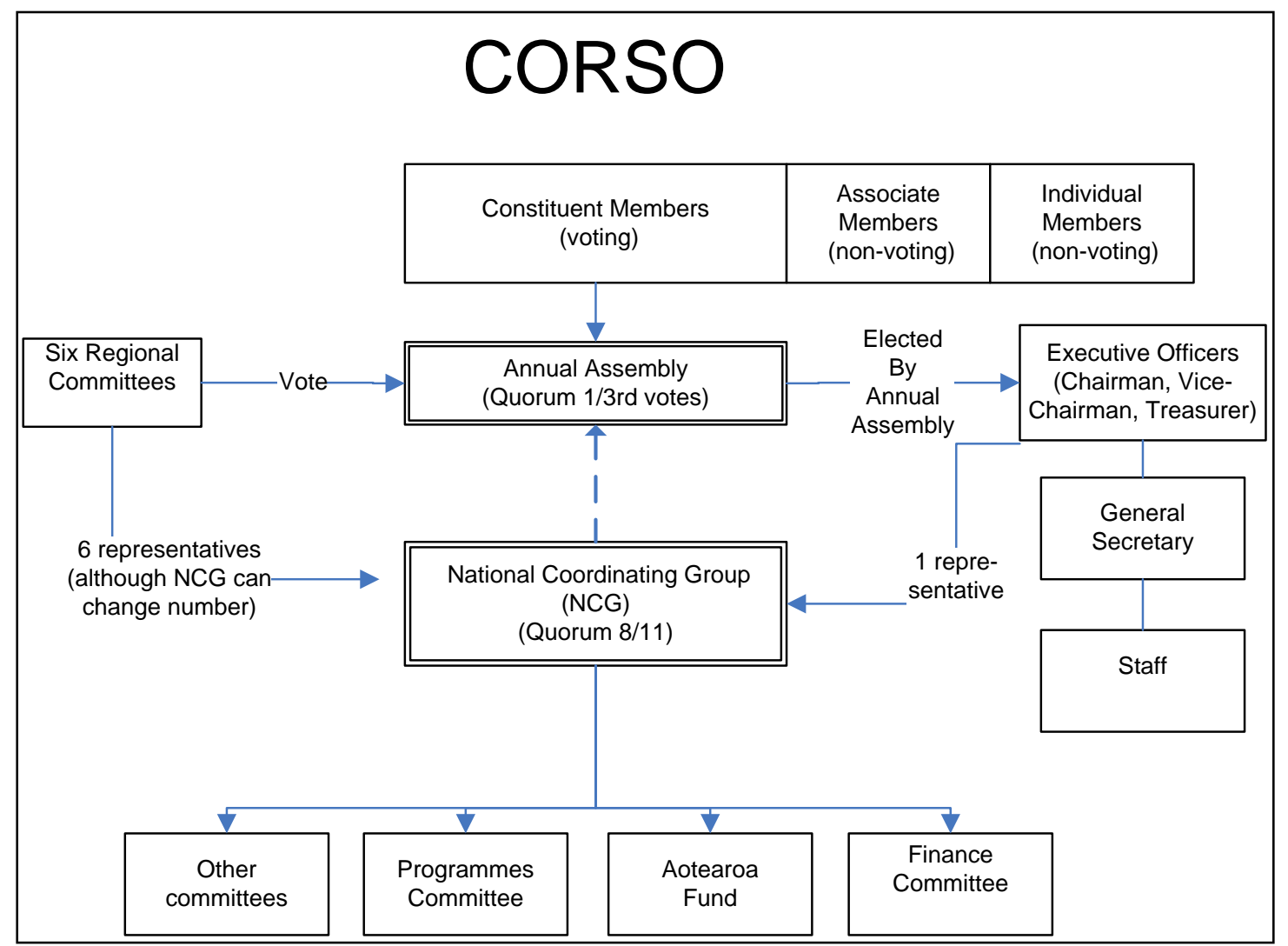

Many of the key voluntary personnel remaining were disenchanted with CORSO's direction and fractiousness and they deserted the organisation in 1990 to establish Oxfam (NZ) (Morrison 1991) as an alternative to supporting World Vision. The Governor-General Dame Catherine Tizard, and prominent New Zealander Sir Edmund Hillary both became patrons of Oxfam, and were among many CORSO supporters switching their allegiance to that organisation (Hutching 1994).

To combat negative press from dissatisfied members, CORSO compared its efficiency in distributing aid with that of Oxfam. It promoted itself as by-passing the international bureaucracies due to its exclusive New Zealand nature. Furthermore, in Issue 42 of Overview (the CORSO magazine) CORSO reported that, for its 1990 Annual Appeal, expenses were only \$13,231 (16.2\%) against \$81,569 income. The report compared CORSO's low spending with Oxfam's target to hold expenses to 
$30 \%$ of income. CORSO further criticised the budgeted advertising expenses of other aid organisations as 'expensive', despite the evidence that such advertising was necessary and effective in attracting funds.

In response to the financial situation and negative media attention in the form of a Frontline television episode in which CORSO's demise was foreshadowed, the organisation cancelled its 1990 annual 'door-knock' collection, preferring a postal appeal. In successive years the limited supporting television advertising was eliminated and envelope distribution restricted to 'high response' areas. This approach was aimed at cost reductions, but unquestionably accelerated CORSO's decline.

The organisation today exists as a marginalised shell of its former self, near the end of its 'long march to obscurity' (McLoughlin 1991). Traces of CORSO exist in two branches (Wellington and Dunedin). CORSO seeks to advance its domestic agenda in relation to Māori development and Tino Rangitiratanga or sovereignty. Beyond this it berates free-trade and bodies established to promote free trade, including the World Trade Organisation and the General Agreement on Tariffs and Trade (GATT). CORSO today opposes New Zealand's role in prescribing free-market approaches to trade for Pacific Island nations, and is politically at the radical left, reflected in its focus on the negative implications of globalisation (Holdom 1997; 1998). In this view transnationals are seen as 'villains'. The IMF is viewed as seeking control of developing countries, imposing demands on them for economic reform as loan conditions. Notably, in recent times orthodox economists of the IMF have arrived at a much more qualified view of the necessary benefits that obtain from free trade and global financial liberalization (Prasad et al. 2003). This gives some support to CORSO's position on international trade. Contemporary CORSO is beyond the purview of this study; however the perception by this body that there is value in the historic 'brand' name of CORSO appears to lead to this GATT 'Watchdog' continuing to use the CORSO name.

\section{Discussion}

Over the years CORSO has come to be viewed as a fringe group promoting a radical agenda. Its focus on attacking capitalism and addressing Māori poverty was a path that the New Zealand public were unwilling to follow (Hutching 1994), coming on top of CORSO's 1970s development agenda which, itself, had been only partially 
supported. While members directly involved in aid had a greater understanding of this agenda and its merits, the general population were not persuaded (Applied Research Consultants 1987) and, instead, increasingly supported new international aid organisations established in direct competition to CORSO. The collapse of this national charity 'brand' marked by first a weakening and then the disappearance of CORSO from its formerly dominant position comprises a type of failure explained by Salamon's (1987) in terms of insufficiency, particularism and donor paternalism.

Initially, CORSO appeared to have sufficient resources to meet its mission. Yet, it shunned these reliable resources and support to make an initially controversial mission change in the direction of development (rather than aid) in 1972. This led to waning public support and potential philanthropic insufficiency (e.g. Otago Daily Times 2000; Survey one 1973). The preference for development initially resonated with neither donors nor supporters, and CORSO's governing body deemed it essential to educate its stakeholders as to the benefits of this approach (e.g. Arnold and Glensor 1974). Their message (backed by Balasuriya 1974) was that crisis aid had been a 'band-aid', but funding well-developed infrastructure in developing countries would reduce the need for such aid. In risking insufficiency with a mission change, CORSO confronted donor paternalism. CORSO's message of development challenged donors' or supporters' commonly held belief that 'deserving poor' needed 'band aids'. New international aid-agencies increasingly espoused similar developmental views, and expanded rapidly in New Zealand (see Figure 4), showing that part of this message was persuasive. Therefore we do not believe that the 'aid vs. development' decision was fatal to CORSO; effectively communicating the reasons for change, and reinstated government support (tax-exempt status), would have enabled CORSO to overcome philanthropic paternalism.

However, philanthropic insufficiency and particularism were different matters, This was evidenced in the rise of international charities in direct competition, in combination with confusion arising from CORSO's changed direction. Insufficiency and particularism describes the voluntary sector's failure to optimally meet beneficiaries' needs. Public scrapping for the donor dollar led to CORSO's inability to generate sufficient resources. A CORSO newsletter accused Oxfam of a 'foreign takeover bid'(Small 1991) and CORSO rebuked Christian Children's Fund for coming to New Zealand (Overview 1991), suggesting there could be duplication of services to particular beneficiaries. In relation to CORSO, its inability to 'beat' the competition to 
the donor dollar caused its failure as a leading charity organisation. By 1977 it had lost its place as the largest charity in New Zealand.

In addition, CORSO's decision to change membership policy exacerbated its voluntary failure. The inclusive membership philosophy that had served the organisation well for thirty years did not allow it to respond appropriately to diverging and increasingly politicised beliefs and objectives. Typically, successful coalitions rely on sufficient goal-based convergence to maintain coherence. Therefore, continuing constituent identities' philanthropic focus required strong, centralised internal control. CORSO's initial non-combative and inclusive approach attempted to broker this goal congruence but did not stand it in good stead when more politically active members joined the organization. The capture of CORSO by factions perceived as radical by the 'heartland' groups resulted in a loss of socio-political legitimacy, to which Fernandez (2008) notes only a small percentage of nonprofit associations succumb. A rift emerged between traditional constituent members (such as Rotary and the Lepers' Trust Board) and newer members, including the University Students' Association (Roger 1974a, 1974b). Disaffection, both internally and throughout the wider community, was a consequence of CORSO's changed political direction. This saw the decline in constituent members from 57 in 1974 to 38 in 1983 (see Appendix 1) and, in turn, reduced financial support from the public for CORSO from 1973. Strong leadership was required to inspire support from the broader constituency, whose active support was uniquely essential to CORSO's fund inflows. While one possible conjecture is that the organisation did not recognise the inextricable link between CORSO's potential for voluntary failure and the continuing need to retain broad-based support to attract funds in the face of governmental apathy or distrust, CORSO also suffered from the government opening up the charity market.

This case study shows that Salamon's (1987) theory of voluntary failure can be extended beyond government support of voluntary organisations to consider supporters of these organisations and the market in which they operate. In the case of CORSO and philanthropic paternalism, it is suggested that donors (rather than CORSO) were paternalistic. Donors expected aid to be delivered overseas and shunned the notion that there could be poverty 'at home' and that Māori sought selfdetermination. In so doing, donors sought to direct wealth toward the 'deserving poor' which they narrowly defined, while CORSO perceived that radical political change was necessary. Therefore, while paternalism could be construed as part of CORSO's 
failure, it was the inability of CORSO to promote radical change to wider stakeholder groups that led to this voluntary failure.

\section{Conclusion}

CORSO began life as a voluntary organisation coordinating activities geared towards overseas relief. As such it was 'home-grown' but eventually failed when international competition captured the donor dollar. This was preceded by an attempt to overcome donor paternalism in the late 1960s, when CORSO focused increasingly on development (rather than aid) to build foundations for impoverished peoples overseas to gain greater self-reliance. This change in strategic direction was insufficiently communicated to the general public, although it was generally accepted within the organisation.

The public disaffection, caused by donor paternalism and the rise of other options for donors, combined to generate philanthropic insufficiency for CORSO. However, it was not an insufficiency that called for government intervention, but one brought on by the rapid growth of similar aid/development organisations. The beneficial move to development (rather than aid) was delayed. No doubt needy people suffered because of this as agencies colluded to encourage donor paternalism.

Key to the demise of this giant in New Zealand charities was the fact that their change in strategic direction resulted in a philosophical shift unsupported by many of its core (orthodox) member bodies. These constituent members had previously supported the deserving poor in a type of philanthropic paternalism (Salamon 1987). CORSO's current focus on local poverty and Māori social justice issues survives in a small coalition choosing to use this persistent, yet impaired, brand name. Their earlier conviction of the appropriateness of their changed vision had blinded them to the importance of retaining socio-political legitimacy. A comparative analysis of similar large organisations in other times and other jurisdictions offers future research potential.

\section{Acknowledgments}

The authors are grateful for the advice of Peter Kitchenman during his time at Victoria University, Wellington; feedback from participants at the Asia-Pacific Economic and Business History Conference, at Queensland in February 2006 and the 
Financial Reporting and Business Communication Conference, Cardiff, July 2007.

We also appreciate the very beneficial comments of joint-editor J. R. Edwards,

Professor Sue Newberry, and the anonymous reviewer. 


\begin{tabular}{|c|c|c|c|c|c|c|c|c|c|c|c|c|c|c|}
\hline \multicolumn{15}{|l|}{ Appendix One: Constituent Me } \\
\hline 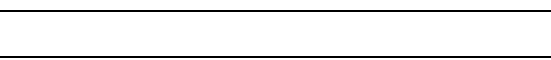 & 62 & 65 & 67 & 69 & 70 & 71 & 72 & 73 & 75 & 78 & 79 & 80 & 82 & 83 \\
\hline \multicolumn{15}{|l|}{ Ass. of Anglican Women } \\
\hline \multicolumn{15}{|l|}{ Ass. of Presbyterian Women } \\
\hline \multicolumn{15}{|l|}{ Baptist Union of NZ } \\
\hline \multicolumn{15}{|l|}{ Boys' Brigade } \\
\hline \multicolumn{15}{|l|}{ British Medical Association } \\
\hline \multicolumn{15}{|l|}{$\begin{array}{l}\text { CARE (Campaign Ass. For Racial } \\
\text { Equality) }\end{array}$} \\
\hline \multicolumn{15}{|l|}{ Catholic Nurses' Guild of NZ } \\
\hline \multicolumn{15}{|l|}{ Catholic Women's' League of NZ } \\
\hline \multicolumn{15}{|l|}{ Chinese Ass. of NZ } \\
\hline \multicolumn{15}{|l|}{ Christian Family Movement } \\
\hline \multicolumn{15}{|l|}{ Christian Pacifist Society } \\
\hline \multicolumn{15}{|l|}{ Committee on Vietnam } \\
\hline \multicolumn{15}{|l|}{ CWS (NCC) } \\
\hline \multicolumn{15}{|l|}{$\begin{array}{l}\text { Divisional Union of Soroptomist } \\
\text { Clubs }\end{array}$} \\
\hline \multicolumn{15}{|l|}{$\begin{array}{l}\text { Dominion } \quad \text { Federation } \\
\text { Townswomen's Clubs }\end{array}$} \\
\hline \multicolumn{15}{|l|}{ Federated Farmers of NZ } \\
\hline \multicolumn{15}{|l|}{$\begin{array}{l}\text { Federation of Business and } \\
\text { Professional Women's Clubs }\end{array}$} \\
\hline \multicolumn{15}{|l|}{ Federation of Country Girl's Clubs } \\
\hline \multicolumn{15}{|l|}{ Federation of Labour } \\
\hline \multicolumn{15}{|l|}{$\begin{array}{l}\text { Federation of NZ Country Women's } \\
\text { Institutes }\end{array}$} \\
\hline Girl Guides' Associations & & & & & & & & & & & & & & \\
\hline $\begin{array}{l}\text { International Relations Committee of } \\
\text { Presbyterian Church }\end{array}$ & & & & & & & & & & & & & & \\
\hline Junior Chamber of Commerce & & & & & & & & & & & & & & \\
\hline $\begin{array}{l}\text { Korean Orphan and Poor Family } \\
\text { Scheme }\end{array}$ & & & & & & & & & & & & & & \\
\hline Lepers' Trust Board & & & & & & & & & & & & & & \\
\hline Leprosy Mission of NZ & & & & & & & & & & & & & & \\
\hline Māori Council & & & & & & & & & & & & & & \\
\hline Māori Women's Welfare League & & & & & & & & & & & & & & \\
\hline Medical Aid Abroad & & & & & & & & & & & & & & \\
\hline Methodist Church in NZ & & & & & & & & & & & & & & \\
\hline Methodist Women's Fellowship & & & & & & & & & & & & & & \\
\hline Nat'l Commission for UNESCO & & & & & & & & & & & & & & \\
\hline National Council of Churches & & & & & & & & & & & & & & \\
\hline National Council of Women (NZ) & & & & & & & & & & & & & & \\
\hline $\begin{array}{l}\text { NZ Catholic } \text { Overseas Aid } \\
\text { Committee }\end{array}$ & & & & & & & & & & & & & & \\
\hline NZ Educational Institute & & & & & & & & & & & & & & \\
\hline NZ Family Planning Ass. & & & & & & & & & & & & & & \\
\hline NZ Federation of University Women & & & & & & & & & & & & & & \\
\hline $\begin{array}{l}\text { NZ Federation of Young Farmer's } \\
\text { Clubs }\end{array}$ & & & & & & & & & & & & & & \\
\hline NZ Friends' Service Committee & & & & & & & & & & & & & & \\
\hline
\end{tabular}




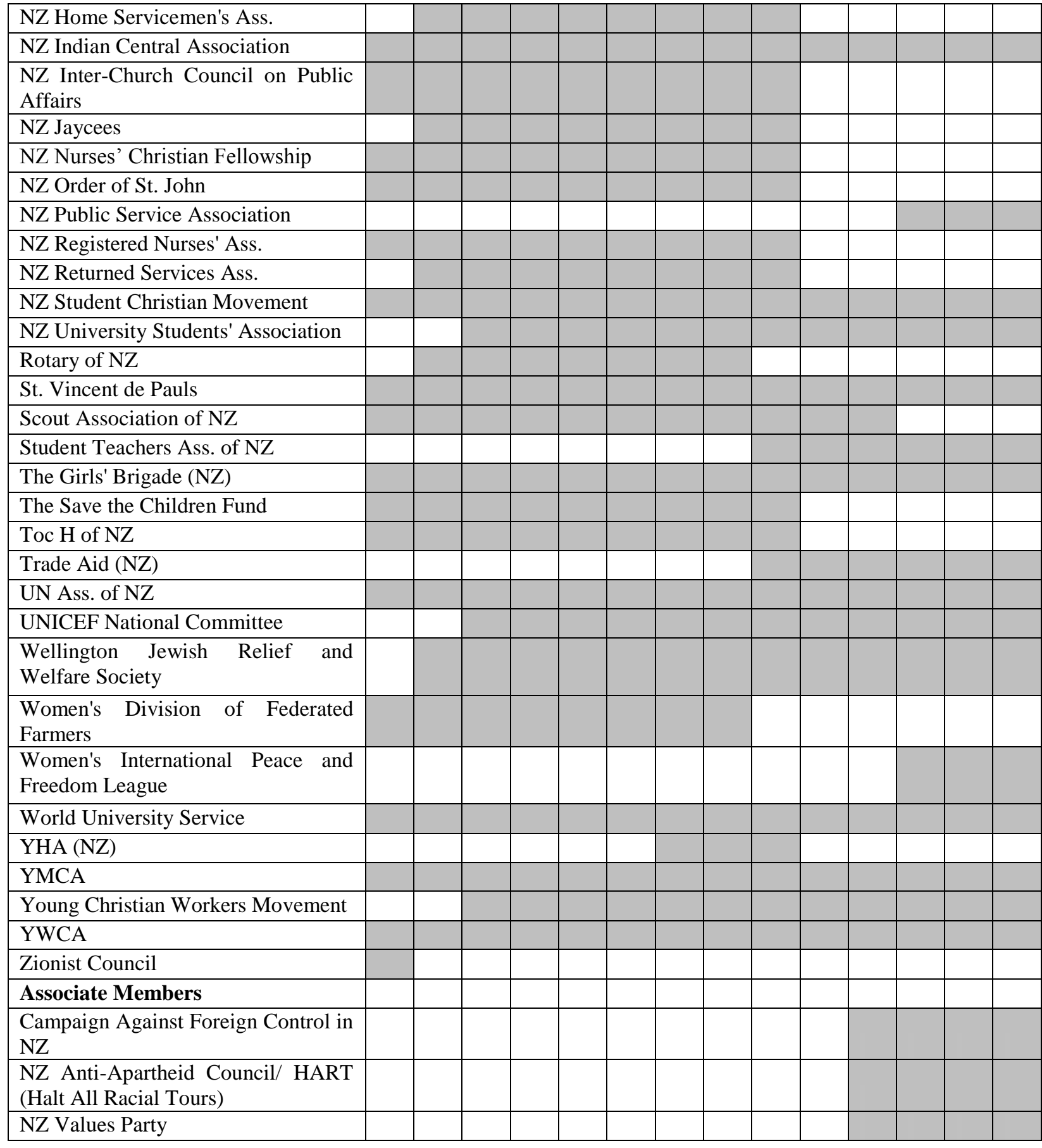

Note: Shaded areas represent the years in which each organisation was a constituent member of CORSO

Notes: 
${ }^{1}$ CORSO's financial statements as early as 1962 included detailed expenditure, and included depreciation.

${ }^{2}$ When considering philanthropy in the NZ context it may be instructive to consider the 'social democratic consensus' that formed New Zealand's social policy from 1935-1966. Armstrong (1994) notes that the ensuing state intervention through social welfare, was very paternalistic, targeting the 'deserving poor'. With this in mind, it is available to interpret the 'emergency aid only' as a response to adverse exigent circumstances, where development, on a puritanical view, implies a fundamental failing on the part of recipients under normal conditions. Tentatively, this may offer some explanation for New Zealand's reluctance to embrace the evolving international appreciation of the need for development.

${ }^{3}$ The Harawira name and its links with Maori activism are well-known in the local community; and it was principally through Harawira that CORSO became more involved in Maori activism.

${ }^{4}$ These were detailed in the Statement of Source and Application of Funds and Schedule of Cash Grants - reporting formats CORSO used from 1980 onwards. 


\section{References}

Primary sources

Alexander Turnbull Library, Wellington.

Applied Research Consultants. 1987. Overseas aid and development: the New Zealand public's attitudes and beliefs: a report prepared for the Advisory Committee on External Aid and Development. Auckland, NZ: The Consultants.

CORSO AGM. 1990. 22 April. Papers relating to CORSO. Ref. 2003-215-10/06.

Duke, E. 1990. Letter from Elizabeth Duke to Mary Woodward, 10 October, 1990. Ref: 2003-215-10/06.

Government Action versus CORSO. 1978-9. Assorted letters. Ref: 90-031-06/1.

Methodist Internal Affairs Committee. 1979. Letter to CORSO. Ref: 90-031-06/1.

National Council of Women. 1979. Letter to CORSO. Ref: 90-031-06/1.

Pencarrow Labour Electorate Committee. 1979. Letter from Pencarrow Labour Electorate Office Secretary McGray to CORSO. Ref: 90-031-06/1.

Research International Ltd. 1973. 2 November. Attitudes to CORSO: Survey Material. Ref: 88-281-22/14.

Survey one. 1973. Attitudes to CORSO: Survey material. Ref: 88-281-22/14.

Trade Aid. 1979. Letter from Trade Aid Chairman to Minister of Foreign Affairs. 27 September. Ref: 90-031-06/1.

Values Party. 1979. Values Party press release, 21 September. Ref: 90-031-06/1.

Volunteer Service Abroad. 1979. Volunteer Service Abroad press release. Ref: 90031-06/1.

Woodward, M. 1990. Letter to Elizabeth Duke. Ref: 2003-215-10/06.

\section{Secondary sources}

Armstrong, N. 1994. State. In New Zealand Society: a sociological introduction, eds P. Spoonley, D. Pearson and I. Shirley, 113-129. Palmerston North: Dunmore Press.

Arnold, A. and P. Glensor. 1974. Action for world development education manual. Wellington: CORSO Education Action Programme.

Balasuriya, Rev. Fr. T. 1974. Development of the poor through civilising the rich. Wellington: CORSO Information Service.

Ben-Ner, A. and B. Gui. 2003. The theory of nonprofit organizations revisited. In Nonprofit and civil society studies, ed. H. K. Anheier, 3-26. New York: Kluver Academic/Plenum Publishers.

Brinkerhoff, J. M. 2008. Diaspora philanthropy in an at-risk society: the case of Coptic Orphans in Egypt. Nonprofit and Voluntary Sector Quarterly 37, no. 3: 411-433. 
Chile, L. M. 2006. The historical context of community development in Aotearoa New Zealand. Community Development Journal 41, no. 4: 407-25.

Consumer. 1993. Overseas aid agencies. How do they spend your money? Consumer No. 317 (July): 24. Wellington: Consumers' Institute.

CORSO Annual Reports. 1955-1986. Wellington: CORSO.

CORSO Gore. 1974. Report and Findings of the $4^{\text {th }}$ Annual CORSO Regional

Conference in Gore. Wellington: CORSO.

CORSO Newsletter. 1978. NO. 74. Christchurch: CORSO. .

CORSO Newsletter. 1986. No. 62. Wellington: CORSO.

CORSO Newsletter. 1994. Christchurch: CORSO.

CORSO. 1976. Auckland and Northland Region: report on activities, 1975-1976. Wellington: CORSO.

CORSO. 1996. Aotearoa New Zealand. Accessed at: http://www.corso.org.nz (Site no longer exists).

CORSO. 1998. GATT watchdog on the South Pacific Forum. Accessed at: http://list.jca.apc.org

Crampton, P., A. Woodward, and T. Dowell. 2000. The role of the third sector in providing primary care services- theoretical and policy issues. Social Policy Journal of New Zealand 17: 1-21.

De Bres, J., R. Campbell, and P. Harris. 1974. Migrant labour in the Pacific.NZ Resource Centre For World Development-CORSO. ACC 90-31, Box 1.

Fernandez, J. J. 2008. Causes of dissolution among Spanish nonprofit associations. Nonprofit and Voluntary Sector Quarterly 37, no. 1: 113-137.

Hansmann, H. 1987. Economic theories of nonprofit organizations. In The Nonprofit Sector: a Research Handbook, ed. W. W. Powell, 27-42. New Haven: Yale University Press.

Hayes, T. 1996. Management, control and accountability in nonprofit/voluntary organizations. Aldershot: Avebury.

Holdom, J. 1997 CORSO. GATT Watchdog. Accessed at: http://www.gatt+wd@corso.ch.planet.gen.nz

Hutching, G. 1994. 50 years old and still on the outer in the aid world. Evening Post, 12 November: 15.

Lineham, P. and A. K. Davidson. 1987. Transplanted christianity. Palmerston North, NZ: Department of History, Massey University,

Lovell-Smith, M. 1986. No turning back: a history of inter-church aid work of the National Council of Churches in New Zealand 1945-1983. Christchurch, NZ: Caxton Press.

McLoughlin, D. 1991. Up in alms; politics in the aid trade. North and South August: $60-8$.

McNamara, R. S. 1973. One hundred countries, two billion people; the dimensions of development. New York: Praeger Publishers. 
Morrison, A. 1991. Why a new charity is rattling the aid chain. Dominion 8 March: 9.

Otago Daily Times. 2000. Kiwis have little idea what foreign aid involves. $19^{\text {th }}$ October: 17. NZPA.

Overview. 1987. Issue 39, August. Wellington: CORSO.

Overview. 1991. Issue 42, June. Wellington: CORSO.

Prasad, E., K. Rogoff, S. Wei, and M. Kose. 2003. Effects of financial globalization on developing countries: some empirical evidence. Washington, DC: International Monetary Fund,

Robbins, G. and I. Lapsley. 2008. Irish voluntary hospitals: an examination of a theory of voluntary failure. Accounting, Business \& Financial History 18 no. 1: 61-80.

Roger, W. 1974a. New influences at work in CORSO: issues behind current rift. Dominion 7 February: 4.

Roger, W. 1974b. CORSO widens aims: controversial decision sets new aid targets. Dominion 8 February: 4.

Salamon, L. 1987. Of market failure, voluntary failure and third-party government: towards a theory of government-nonprofit relations in the modern welfare state. Nonprofit and Voluntary Sector Quarterly 16, no. 1/2: 29-49.

Seibel, W. and H. K. Anheier. 1990. Sociological and political science approaches to the third sector. In The Third Sector, Comparative Studies of Nonprofit Organisations, eds. H. K. Anheier and W. Seibel, 7-20. New York: Walter de Gruyter.

Small, D. 1991. Overseas alms dealers target NZ market. CORSO Newsletter.

Small, D. 1997. Development education revisited: the New Zealand experience. International Review of Education 43, no. 5/6: 581-94.

Tennant, M. 2001. Governments and voluntary sector welfare: historians' perspectives. Social Policy Journal of New Zealand 17: 147-60.

Tennant, M., M. O'Brien, and J. Sanders. 2008. The history of the non-profit sector in New Zealand. Wellington, NZ: Office for the Community and Voluntary Sector.

Thompson, R. T. 1969. New Zealand in development - a record of overseas aid. Wellington, NZ: Wright and Carman.

Weisbrod, B. A. 1988. The nonprofit economy. Cambridge, MA: Harvard University Press. 